\title{
Acute pericarditis due to pegylated interferon alpha therapy for chronic HCV hepatitis - Case report
}

\author{
Cristina Popescu*, Victoria Arama and Smaranda Gliga
}

\begin{abstract}
Background: Cardio toxicity due to interferon therapy was reported only in small case series or case reports. The most frequent cardiac adverse effects related to interferon are arrhythmias and ischemic manifestations. The cardiomyopathy and pericarditis are rare but can be life threatening. The predisposing factors for interferon cardio toxicity were described only for ischemic manifestations and arrhythmias.
\end{abstract}

Case presentation: The authors report a case of pericarditis due to alpha interferon therapy for chronic hepatitis

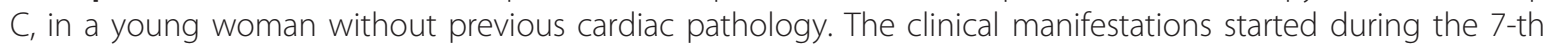
month of interferon treatment. The cessation of interferon was necessary. After interferon discontinuation the patient recovered, with complete resolution of pericarditis. The patient scored 9 points on the Naranjo ADR probability scale, indicating a very probable association between pericarditis and interferon administration.

Conclusion: If a patient receiving interferon therapy complains of chest pain of sudden onset, a cardiac ultrasound should be performed in order to rule out pericarditis. We point out the possibility of an infrequent but severe adverse effect of interferon therapy.

\section{Background}

Pegylated interferon plus ribavirin represents the gold standard therapy for hepatitis $\mathrm{C}$ virus (HCV) but various side effects may occur, limiting its efficacy [1,2]. Although some of these adverse effects are rarely reported, their severity can be higher than expected, sometimes leading to a life-threatening event. The diversity of the described adverse effects may increase because of the high number of patients who receive treatment for HCV hepatitis. Their monitoring and reporting is important in order to facilitate subsequent recognition of similar cases.

We report a case of acute pericarditis without tamponade which was correlated with pegylated interferon alpha 2a treatment for chronic HCV hepatitis.

\section{Case Presentation}

A 38-year-old white female, without previous cardiac pathology, was being monitored and treated for chronic HCV hepatitis, genotype I virus. She was started on a combination treatment with peginterferon alpha $2 \mathrm{a}$

\footnotetext{
* Correspondence: crispopescu3@yahoo.com

'Matei Bals' National Institute of Infectious Diseases, University of Medicine and Pharmacy 'Carol Davila' Bucharest, Grozovici 1, sector 2, Romania
}

(180 $\mu \mathrm{g}$ weekly) and ribavirin (1000 mg daily, according to her body weight). The patient had complete early virologic response (HCV-RNA was undetectable at 12 weeks of treatment). In the first seven months of treatment no severe side effects (hematologic, endocrine, ophthalmic or autoimmune) were observed.

In the $7^{\text {th }}$ month of treatment the patient accused chest pain, dry cough, fatigue, dyspnea, without fever and she presented herself to the emergency room.

On physical examination we found: tachypnea (22-24/ $\mathrm{min})$, tachycardia $(96 / \mathrm{min})$, a blood pressure of $100 / 70$ $\mathrm{mmHg}$ with pulmonary and abdominal examination within the normal limits. Cardiac examination revealed a third heart sound over the precordium as well as muffled cardiac sounds. The pulmonary X-ray was normal and the ECG showed no specific repolarisation abnormalities. Trans-thoracic cardiac ultrasonography revealed a pericardial effusion without tamponade. Laboratory data revealed: mild leukopenia, anemia, thrombocytopenia (which didn't need reduction of interferon or ribavirin doses), minor biological inflammatory syndrome (CRP - $17 \mathrm{mg} / \mathrm{l})$. The hepatic enzymes were normal, HCV-RNA was undetectable, serological tests for viruses and bacteria which could have explained the 
pericarditis were negative: ECHO, Coxsackie, adenovirus, influenza virus, parainfluenza virus, EBV, CMV, HIV, Mycoplasma pneumoniae, Chlamydia pneumoniae, Rickettsia spp, Legionella pneumophila, Borrelia burgdorferii. Serological tests for viruses remained negative for the following 2 weeks. Quantiferon TB gold was negative. The patient didn't receive antimycobacterial medication. The ASO titer was in the normal range. Autoimmune tests were performed, with negative antinuclear factor, anti-DNA antibodies, p ANCA, c ANCA, anti-mitochondrial antibody, anti-Ro and anti-La antibodies and negative cryoglobulinemia. Thyroid function tests were normal, and anti tyreo-peroxidase antibodies were absent.

The antiviral medication was stopped and the patient received ibuprofen. The symptoms disappeared and the pericardial effusion resolved in 15 days.

Because the patient was infected with genotype 1 virus and detection of HCV-RNA at 4 weeks of treatment was not performed (in order to confirm a rapid virological response), the antiviral treatment was restarted only with pegylated interferon. After the first dose of interferon administration symptoms reappeared. The echocardiography showed an increase of pericardial fluid (at 24 hours after interferon administration). The antiviral medication was stopped again with rapid recovery.

Six months after discontinuation of treatment, the HCV-RNA was undetectable (the patient had sustained virologic response).

The correlation of pericarditis with interferon administration was appreciated, for the presented case using the Naranjo ADR probability scale, which summed up 9 points, indicating a very probable association (table 1) [3].

\section{Discussion}

Interferon plays an essential role in the mechanisms of defense against infections, being produced by a variety of cells. Until now two types of interferon have been identified: type I (alpha and beta interferon), which blocks the translation and viral replication and type II (gamma interferon), which initiates the synthesis of chemical substances with antiviral properties [4]. On top of the positive effects, the administration of interferon can be associated with many unwanted adverse effects because of the destruction of uninfected cells. The prevalence of life threatening complications during the interferon treatment is less then $1 \%$. The cardio toxicity of interferon has been even rarely reported, only in small series of patients, and often just in isolated cases [5]. Among the three types of interferon, the alpha interferon is the most cardio toxic, followed by beta and gamma interferon.

The mechanism through which interferon is cardio toxic has not been clearly demonstrated $[6,7]$, but it is
Table 1 NARANJO ADR PROBABILITY SCALE calculated for our case summed up 9 points, indicating a very probable association between acute pericarditis and interferon treatment

\begin{tabular}{|c|c|c|}
\hline Question & Response & Points \\
\hline $\begin{array}{l}\text { Are there previous conclusion reports on this } \\
\text { reaction? }\end{array}$ & Yes & +1 \\
\hline $\begin{array}{c}\text { Did the adverse event appear after the suspect } \\
\text { drug was administered? }\end{array}$ & Yes & +2 \\
\hline $\begin{array}{l}\text { Did the AR improve when the drug was } \\
\text { discontinued or a specific antagonist was } \\
\text { administered? }\end{array}$ & Yes & +1 \\
\hline $\begin{array}{l}\text { Did the AR reappear when drug was } \\
\text { readministered? }\end{array}$ & Yes & +2 \\
\hline $\begin{array}{c}\text { Are there alternate causes [other than the } \\
\text { drug] that could solely have caused the } \\
\text { reaction? }\end{array}$ & No & +2 \\
\hline $\begin{array}{l}\text { Did the reaction reappear when a placebo was } \\
\text { given? }\end{array}$ & $\begin{array}{l}\text { don't } \\
\text { know }\end{array}$ & 0 \\
\hline $\begin{array}{l}\text { Was the drug detected in the blood [or other } \\
\text { fluids] in a concentration known to be toxic? }\end{array}$ & No & 0 \\
\hline $\begin{array}{l}\text { Was the reaction more severe when the dose } \\
\text { was increased, or less severe when the dose } \\
\text { was decreased? }\end{array}$ & $\begin{array}{l}\text { don't } \\
\text { know }\end{array}$ & 0 \\
\hline $\begin{array}{c}\text { Did the patient have a similar reaction to the } \\
\text { same or similar drugs in any previous } \\
\text { exposure? }\end{array}$ & No & 0 \\
\hline $\begin{array}{l}\text { Was the adverse event confirmed by objective } \\
\text { evidence? }\end{array}$ & Yes & +1 \\
\hline Total & & 9 \\
\hline
\end{tabular}

presumed that at least two factors are implicated: the deterioration of endothelial cells inducing the overlay of immune complexes at this level; and stimulation of TNF alpha, IL 2, IL 6, IL 1 release, that influence the vasopressor response.

The most common cardio toxic clinical effects of interferon are: arrhythmias- 58\%, acute coronary syndrome- $21 \%$, cardiomiopathies- $12 \%$ and other manifestations - 9\% (including pericarditis) [5]. There are no described predisposing factors for interferon cardio toxicity.

Acute pericarditis is determined by a multitude of causes: infectious, neoplastic, uremia, autoimmune, traumatic, drug induced. Concerning drug toxicity, there have been reported cases of acute pericarditis after the administration of: hydralazine, procainamide, izoniazid, phenylbutazone, dantrolene, doxorubicin, penicillin, these situations being extremely rare. Interferon is not cited by the ESC Guidelines on the Diagnosis and Management of Pericardial Diseases [8] as one of the causes of drug induced pericarditis.

Acute pericarditis, as a consequence of interferon treatment is extremely rare. So far, very few cases of pericarditis related to administration of interferon have been reported; some of these patients received interferon for neoplastic diseases such as melanoma or acute 
leukemia $[9,10]$. The role of ribavirin in the pathogenesis of pericarditis could be considered. In our case, we restarted only interferon therapy (after two weeks of discontinuation), which concluded in the reappearance of pericardial effusion.

Six cases of pericarditis due to interferon alpha have been reported in patients with chronic HCV hepatitis. Three of these patients had an underlying pathology that could explain the pericarditis: Sikole et al. reported a case of pericarditis among hemodialysis patients receiving interferon for hepatitis C [11], Suarez A et al described a case of pericarditis in a patient with cryoglobulinemia [12], Boonen et al. reported a case of pericarditis during the treatment of chronic HCV hepatitis as part of a lupus-like syndrome, with clinical manifestations of autoimmune pathologies [13]. Recently Kazuahi Nishio et al described a case of pericarditis related to pegylated interferon therapy for HCV hepatitis. This patient had positive anti-DNA and anti-ds DNA IgM antibodies [14]. The case of pericarditis reported by Gressens B et al in conjunction with the administration of interferon occurred four months after stopping the treatment [15].

We are reporting a very rare adverse effect of pegylated interferon treatment- acute toxic pericarditis, this being the second case observed in a patient with no underlying pathology, described in the medical literature. The first case was reported by Wisniewski B et al; pericarditis occurred in this case after the first dose of interferon [16].

In summary, we report a patient without any history of cardiac disease who developed pericarditis after interferon treatment. Reappearance of symptoms when the antiviral treatment was restarted indicates a strong correlation between drug and adverse effects [3]. The effect of the virus itself is quite unlikely (undetectable HCVRNA). The clinical and biological markers of a possible associated autoimmune pathology were absent. We excluded a viral or bacterial (including tuberculosis) etiology of pericarditis.

\section{Conclusions}

We consider that in a patient receiving interferon, pericarditis must be evoked if the patient accuses sudden chest pain. It is of most importance that a cardiac ultrasound should be performed in a situation like this.

\section{Consent}

Written informed consent was obtained from the patient for publication of this case report and any accompanying images. A copy of the written consent is available for review by the Editor-in-Chief of this journal.

\footnotetext{
Abbreviations

HCV: hepatitis C virus; HCV-RNA: hepatitis C virus - ribonucleic acid; ECG: electrocardiogram; CRP: C reactive protein; EBV: Epstein Barr Virus; CMV:
}

cytomegalovirus; HIV: human immunodeficiency virus; DNA: deoxyribonucleic acid; c ANCA: classical antineutrophil cytoplasmic antibodies; p ANCA: protoplasmic-staining antineutrophil cytoplasmic antibodies; ADR: adverse drug reaction; TNF: tumor necrosis factor; IL6: interleukin 6; IL2: interleukin 2; IL1: interleukin 1; ESC: European Society of Cardiology

\section{Acknowledgements}

This paper is partially supported by the Sectoral Operational Programme Human Resources Development (SOP HRD), financed from the European Social Fund and by the Romanian Government under the contract number POSDRU/89/1.5/S/64109

\section{Authors' contributions}

CP and VA contributed equally to this work; CP, VA, SG performed a review of the literature; CP and VA take care of the patient; CP, VA have been involved in drafting the manuscript and revising it critically; CP, VA and SG wrote and revised the paper before submission.

All authors read and approved the final manuscript

\section{Authors' information}

CP - assistant professor at Carol Davila University of Medicine in Bucharest, MD from 1995, PhD from 2005, infectious diseases specialist from 2000, with a postdoctoral bursary supported by the Sectoral Operational Programme Human Resources Development financed from the European Social Fund and by the Romanian Government. CP is the co-author of 4 books, more than 50 studies communicated to national and international medical conferences.

AV - associated professor at Carol Davila University of Medicine in Bucharest, MD from 1987, PhD from 1999, infectious diseases specialist from 1993. AV is the head of Third Department in Matei Bals National Institute of Infectious Diseases. VA is the author of more than 10 medical books and she published more than 100 medical papers, and communicated more than 100 medical studies.

SG - MD from 2009, resident physician in infectious diseases

\section{Competing interests}

The authors declare that they have no competing interests.

1. Financial competing interests

- In the past five years I did not received reimbursements, fees, funding, or salary from an organization that may in any way gain or lose financially from the publication of this manuscript, either now or in the future.

- I do not hold any stocks or shares in an organization that may in any way gain or lose financially from the publication of this manuscript, either now or in the future.

- I do not hold and I am not currently applying for any patents relating to the content of the manuscript. I have not received reimbursements, fees, funding, or salary from an organization that holds or has applied for patents relating to the content of the manuscript.

- I have not any other financial competing interests.

2. Non-financial competing interests

There are not any non-financial competing interests (political, personal, religious, ideological, academic, intellectual, commercial or any other) to declare in relation to this manuscript.

Received: 5 December 2010 Accepted: 31 March 2011

Published: 31 March 2011

\section{References}

1. Dusheiko G: Side effects of alpha interferon in chronic hepatitis C. Hepatology 1997, 26:112S-121S.

2. Negro F: Adverse effects of drugs in the treatment of viral hepatitis. Best Pract Res Clin Gastroenterol 2010, 24:183-92.

3. Naranjo CA, Busto U, Sellers EM, et al: A method for estimating the probability of adverse drug reactions. Clin Pharmacol Ther 1981, 30:239-45.

4. LiU YJ: IPC: professional type 1 interferon-producing cells and plasmacytoid dendritic cell precursors. Annu Rev Immunol 2005, 23:275-306

5. Rechciński T, Matusik D, Rudziński T, et al: Cardiotoxic properties of interferon: aggravation of atrio-ventricular block during treatment of 
chronic hepatitis C with peginterferon-a case report. Pol Arch Med Wewn 2007, 117:49-52.

6. Outzen MA, Crowley S: Interferons Play a Central Role in the Natural Defense and Therapeutic Management of Hepatitis C: A Review. The Internet Journal of Gastroenterology 2007, 5(2).

7. Takahashi H, Nishimura M, Sakamoto M, Ikegaki I, Nakanishi T, Yoshimura M: Effects of interleukin-1 beta on blood pressure, sympathetic nerve activity, and pituitary endocrine functions in anesthetized rats. Am J Hypertens 1992, 5:224-9.

8. Maisch B, Seferović PM, Ristic AD, et al: Guidelines on the diagnosis and management of pericardial diseases executive summary; The Task force on the diagnosis and management of pericardial diseases of the European society of cardiology. Eur Heart J 2004, 25:587-610.

9. Benjamini O, Kimhi O, Lishner M: Severe pleuropericarditis and cardiomyopathy induced by high dose interferon alpha-2b. Isr Med Assoc J 2007, 9:486-7.

10. Fava S, Luoni M, Stioui S: Pericarditis during interferon-alpha therapy in chronic myelogenous leukemia. Haematologica 1996, 81:484.

11. Sikole A, Dzekova P, Selja N, et al: Treatment of hepatitis C in hemodialysis patients with pegylated interferon alpha-2a as monotherapy. Ren Fail 2007, 29:961-6.

12. Suárez A, Vallina E, Navascués CA, et al: Mixed type-ll cryoglobulinemia associated with a chronic hepatitis C virus infection. Rev Clin Esp 1993, 192:325-6.

13. Boonen A, Stockbrügger RW, van der Linden S: Pericarditis after therapy with interferon-alpha for chronic hepatitis. C Clin Rheumatol 1999, 18:177-9.

14. Nishio Kazuaki, Konndo Takeshi, Shunichi Okada, et al: Pericarditis and chronic inflammatory demyelinating polyneuropathy during therapy with pegylated interferon alfa-2a for chronic hepatitis C. World I Hepatol 2010, 2:358-61.

15. Gressens B, Gohy P: Pericarditis due to interferon-alpha therapy during treatment for chronic hepatitis C. Acta Gastroenterol Belg 2004, 67:301-2.

16. Wisniewski B, Denis J, Fischer D, Labayle D: Pericarditis secondary to interferon alpha in chronic hepatitis C. Gastroenterol Clin Biol 2004, 28:315-6.

\section{Pre-publication history}

The pre-publication history for this paper can be accessed here: http://www.biomedcentral.com/1471-230X/11/30/prepub

doi:10.1186/1471-230X-11-30

Cite this article as: Popescu et al:: Acute pericarditis due to pegylated interferon alpha therapy for chronic HCV hepatitis - Case report. BMC Gastroenterology 2011 11:30.

\section{Submit your next manuscript to BioMed Central and take full advantage of:}

- Convenient online submission

- Thorough peer review

- No space constraints or color figure charges

- Immediate publication on acceptance

- Inclusion in PubMed, CAS, Scopus and Google Scholar

- Research which is freely available for redistribution

Submit your manuscript at www.biomedcentral.com/submit
Biomed Central 